\title{
Effects of Nano Fertilizer on Yield, Yield Attributes and Economics in Tomato (Solanum lycopersicum L.)
}

\author{
Janmejaya Panda ${ }^{1}$, Alok Nandi ${ }^{1}$, Siba Prasad Mishra ${ }^{2}$, Asit Kumar Pal $^{3}$, \\ Ajoy Kumar Pattnaik ${ }^{1}$ and Nitish Kumar Jena ${ }^{1}$
}

${ }^{1}$ Department of Horticulture, Institute of Agricultural Sciences, Siksha 'O' Anusandhan (Deemed To Be University), Bhubaneswar-751029, Odisha, India

${ }^{2}$ Krishi Vigyan Kendra, Odisha University of Agriculture and Technology, Jajpur, Odisha, India

${ }^{3}$ Department of Soil Science and Agricultural Chemistry, Institute of Agricultural Sciences, Siksha 'O' Anusandhan (Deemed To Be University), Bhubaneswar-751029, Odisha, India *Corresponding author

\section{A B S T R A C T}

\begin{tabular}{|c|}
\hline Keywords \\
\hline $\begin{array}{l}\text { Tomato, Nano } \\
\text { fertilizer, Yield, } \\
\text { Foliar spray, } \\
\text { Economics }\end{array}$ \\
\hline Article Info \\
\hline $\begin{array}{l}\text { Accepted: } \\
18 \text { April } 2020 \\
\text { Available Online: } \\
10 \text { May } 2020\end{array}$ \\
\hline
\end{tabular}

An experiment was undertaken during the winter season of 2018-19 on tomato (var. Utkal Pallavi), in order to assess the performance of new commercial nano-based water soluble, foliar fertilizer in comparison to commonly adopted water soluble foliar fertilizer with respect to yield, yield attributes and economics. The experiment was laid out in the randomized block design with eight treatments and three replications. Results revealed that the treatment $\mathrm{T}_{6}$ (Pramukh foliar spray@5g/1 + RDF- Recommended Dose of Fertilizer@ $125 \mathrm{~kg} \mathrm{~N}: 60 \mathrm{~kg} \mathrm{P}_{2} \mathrm{O}_{5}: 100 \mathrm{~kg} \mathrm{~K} 2 \mathrm{O} / \mathrm{ha}$ ) was found to be the best with respect to the characters like fruit yield (510 q/ha), fruits per plant $(81.6)$, fruit length $(5.84 \mathrm{~cm})$ and fruit girth $(14.13 \mathrm{~cm})$. As regards average fruit weight, $\mathrm{T}_{3}$ (Nano- Max NPK foliar spray $@ 5 \mathrm{ml} / 1+\mathrm{RDF})$ was the best $(56.3 \mathrm{~g})$. The treatment $\mathrm{T}_{5}$ (Pramukh foliar spray @4g/l + RDF) produced the maximum no. of flowers per cluster (9.73) and recorded the highest benefit: cost ratio (3.69). As regards days to $50 \%$ flowering, $\mathrm{T}_{1}$ and $\mathrm{T}_{3}$ recorded early $50 \%$ flowering (51.0 days after sowing). The treatment $\mathrm{T}_{5}$ produced $2^{\text {nd }}$ highest yield (509.26q/ha) followed by the treatment $\mathrm{T}_{6}$ having highest yield and $2^{\text {nd }}$ highest benefit: cost ratio (3.68).

\section{Introduction}

Nanotechnology encompasses understanding of the fundamentals involving physics, chemistry, biochemistry, biology and technology of nanometer-scale objects. It deals with very small sized particles which range between $1 \mathrm{~nm}$ to $100 \mathrm{~nm}$. Medicine, water and soil management, nano-fertilizers, pesticides, food technology, nano sensors, solar cells, electronics etc. are the various areas in which nanotechnology has been applied. Nano fertilizers can eliminate or lessen the problems such as leaching of nutrients, environmental pollution, plant damage, increasing salinity and toxicity etc. 
caused by use of conventional inorganic fertilizers. Nano fertilizers are extremely soluble, provide precise concentration and slow release of nutrients due to greater surface area. These are also safer than the conventional inorganic fertilizers from the angle of soil and environmental degradation.

Tomato is globally known as "Protective Food". It contains vitamin-C and lycopene which is an antioxidant. It increases appetite and relieves constipation. As regards nano fertilizer, there are numerous uses of these fertilizers to increase the yield and growth of different crops. Tantawy et al., (2014) reported that tomato fruit yield and nutritional status were significantly improved under nano calcium treatment of $0.5 \mathrm{~g} / 1$ concentration. Ambroszczyk et al., (2016) showed that foliar application of Nano-Gro® increased early yield of tomato fruit $\left(983 \mathrm{~g} / \mathrm{m}^{2}\right)$ as compared with the control $\left(780 \mathrm{~g} / \mathrm{m}^{2}\right)$ and also increased lycopene, dry matter, chlorophyll and $\beta$ carotene content. Also, Khan (2016) observed that nano-titanium dioxide $\left(\mathrm{Nano}-\mathrm{TiO}_{2}\right)$ @ $20 \mathrm{mg} / 1$ as foliar spray enhanced growth and yield, antioxidative enzymes and accumulation of compatible solutes [Proline and Glycine Betaine] in tomato grown under $200 \mathrm{mM} \mathrm{NaCl}$.

No research work has been conducted in Odisha as regards application of nano fertilizers in tomato. Therefore, an experiment was carried out with the objective of studying the effects of commercial nano-NPK fertilizer on yield, yield attributing characters and economics of treatments in tomato.

\section{Materials and Methods}

The experiment was conducted in the experimental field under the Department of Horticulture, Institute of Agricultural Sciences, Siksha 'O' Anusandhan (Deemed to be University), Bhubaneswar, during the winter season of 2018-19. The field was laid out in randomized block design with 8 treatments and 3 replications while spacing of $50 \mathrm{~cm}$ between rows and $30 \mathrm{~cm}$ between plants was given.

\section{Mechanical composition of soil}

The mechanical composition of initial soil sample was determined by Bouyoucos Hydrometer method, 1962. The textural class of the soil was loamy sand and the composition of sand, silt and clay were $79.6 \%, 14.3 \%$ and $6.1 \%$ respectively. The chemical composition of the initial soil sample is given in Table 1.

\section{Nano-max NPK}

The constituents of this fertilizer are multiple organic acids (protein lacto-gluconates) containing chelated major nutrients $(\mathrm{N}: \mathrm{P}: \mathrm{K} @$ $4: 4: 4 \%)$ along with organic carbon $(10 \%)$ and amino acids (6\%). Manufacturer- J.U. Agri Science Pvt. Ltd., Indore, MP.

\section{Multiplex pramukh}

This fertilizer is constituted of N:P:K @ $19: 19: 19 \%$. It is water soluble fertilizer which can be used as foliar spray or in fertigation. Manufacturer- Agriplex Pvt. Ltd., Mahalakshmi Layout, Bengaluru, Karnataka. Seeds of tomato var. Utkal Pallavi were sown in the nursery bed on 23.10.2018 and transplanting was done on 19.11.2018.Before transplanting, FYM @25t/ha was applied to the main field. Recommended basal dose of Urea (20\%), Single Super Phosphate (100\%) and Muriate of Potash $(20 \%)$ were also applied to the main field. Fifteen days after transplanting, Urea $(40 \%)$ and Muriate of Potash (40\%) were applied as first top dressing and thirty days after transplanting, the remaining $40 \%$ Urea and Muriate of Potash was applied as second top dressing. Respective doses of Nano-Max NPK and 
Pramukh fertilizers were applied three times to the subplots on $04.12 .2018,19.12 .2018$ and 04.01.2019 respectively. Recommended packages were adopted for all other cultural practices.

Five sample plants were tagged randomly from different sub plots leaving the border plants for recording observations. Observations on days to $1^{\text {st }}$ flowering, days to $50 \%$ flowering, flowers per cluster, fruit length, fruit girth, fruit weight, fruits per plant, fruits per cluster and fruit yield were recorded systematically and periodically.

Plot yields were recorded at 4-5 days interval and the total yield was expressed in terms of quintals per hectare. The data were statistically analysed for randomized block design as suggested by Panse and Sukhatme (1985) (Table 2).

\section{Results and Discussion}

\section{Days to $1^{\text {st }}$ flowering (Days after sowing)}

No significant differences were observed regarding days to $1^{\text {st }}$ flowering. However, the values ranged from 44.33 days to 47.67 days after sowing (Table 3). The treatment $\mathrm{T}_{4}$ produced early flowering in 44.33 days after sowing followed by $\mathrm{T}_{8}$ and $\mathrm{T}_{6}$. Late flowering (47.67 days after sowing) was seen in $T_{1}$.

\section{Days to $50 \%$ flowering (Days after sowing)}

There were no significant differences with regard to days to $50 \%$ flowering (Table 3). The values in this respect ranged between 51 days and 53.67 days after sowing. However, $\mathrm{T}_{1}$ and $\mathrm{T}_{3}$ gave early $50 \%$ flowering in 51 days followed by $\mathrm{T}_{8}$ and $\mathrm{T}_{6}$ treatments. The late (53.67 days after sowing) 50\% flowering was obtained in $\mathrm{T}_{7}$ treatment. The fact that $\mathrm{T}_{1}$ and $\mathrm{T}_{3}$ gave early $50 \%$ flowering conforms to the findings of Laware and Raskar (2014) and Shukla et al., (2017).

\section{Flowers per cluster}

No significant differences were found with regard to no. of flowers per cluster (Table 3). However, the values ranged between 8.73 and 9.73. $\mathrm{T}_{5}$ treatment produced the maximum (9.73) no. of flowers per cluster followed by $\mathrm{T}_{3}$ and $\mathrm{T}_{8}$. The least value (8.73) was observed in case of $\mathrm{T}_{1}$ treatment.

\section{Fruit weight (g)}

Significant differences were observed with respect to fruit weight of tomato plants, which ranged from $49.83 \mathrm{~g}$ to $56.93 \mathrm{~g}$ (Table 4). However, $\mathrm{T}_{3}, \mathrm{~T}_{7}, \mathrm{~T}_{8}, \mathrm{~T}_{2}, \mathrm{~T}_{6}$ and $\mathrm{T}_{4}$ treatments showed similar results. $T_{3}$ gave significantly better result than $\mathrm{T}_{1}$ and $\mathrm{T}_{5}$. Yassen et al., (2017) also reported that fruit weight was better with nano-fertilizer application. Highest fruit weight $(56.93 \mathrm{~g})$ was seen in case of $\mathrm{T}_{3}$ and the lowest $\left(49.83 \mathrm{~g}\right.$ ) in case of $\mathrm{T}_{1}$.

\section{Fruit length (cm)}

It was evident from Table 4 that there were no significant differences among treatments with regard to fruit length, which ranged between $5.44 \mathrm{~cm}$ and $5.84 \mathrm{~cm}$.

However, $\mathrm{T}_{6}$ produced maximum $(5.84 \mathrm{~cm})$ fruit length followed by $\mathrm{T}_{2}$ and $\mathrm{T}_{3}$. This is in consonance with the reports of Yassen et al., (2017). The lowest value $(5.44 \mathrm{~cm})$ was observed in $\mathrm{T}_{5}$.

\section{Fruit girth (cm)}

It was observed from Table 4 that there were significant differences in case of fruit girth, which ranged from $12.34 \mathrm{~cm}$ to $14.13 \mathrm{~cm} . \mathrm{T}_{6}$, $\mathrm{T}_{7}, \mathrm{~T}_{2}, \mathrm{~T}_{3}$ and $\mathrm{T}_{8}$ were at par and $\mathrm{T}_{1}, \mathrm{~T}_{5}$ and $T_{4}$ were inferior to $T_{6}$. The treatments $T_{8}, T_{4}$, $\mathrm{T}_{5}$ and $\mathrm{T}_{1}$ recorded similar results. $\mathrm{T}_{6}$ gave maximum $(14.13 \mathrm{~cm})$ and $\mathrm{T}_{1}$ gave minimum $(12.34 \mathrm{~cm})$ fruit girth. 
Table.1 Chemical composition of initial soil sample

\begin{tabular}{|c|c|c|}
\hline Particulars & $\begin{array}{c}\text { Value } \\
\text { obtained }\end{array}$ & Method \\
\hline Organic carbon (\%) & 0.6 & Walkley and Black's rapid titration (1934) \\
\hline Total N (kg/ha) & 48 & $\begin{array}{c}\text { Total nitrogen content }(\mathrm{kg} / \mathrm{ha})=\% \text { of organic } \\
\text { carbon x 80 }\end{array}$ \\
\hline Available P (kg/ha) & 3.76 & Olsen's method(1954) \\
\hline Available K (kg/ha) & 126.6 & $\begin{array}{c}\text { Flame-Photometer using ammonium acetate } \\
\text { extracts (Jackson, 1973) }\end{array}$ \\
\hline pH(1:2.5::Soil:water) & 6.5 & $\begin{array}{l}\text { pH meter with 1:2.5 soil water ratio(Jackson, } \\
\text { 1973) }\end{array}$ \\
\hline Electrical conductivity $(\mu S)$ & 111.6 & Electrical conductivity meter \\
\hline
\end{tabular}

Table.2 Details of treatments

\begin{tabular}{|c|l|}
\hline Sl. No. & \multicolumn{1}{c|}{ Treatments } \\
\hline $\mathbf{T}_{1}$ & Nano-Max NPK @ 3ml/l of water foliar spray + RDF \\
\hline $\mathbf{T}_{\mathbf{2}}$ & Nano-Max NPK @ 4ml/l of water foliar spray + RDF \\
\hline $\mathbf{T}_{3}$ & Nano-Max NPK @ 5ml// of water foliar spray + RDF \\
\hline $\mathbf{T}_{4}$ & Pramukh @ 3g/l of water foliar spray + RDF \\
\hline $\mathbf{T}_{5}$ & Pramukh @ 4g/l of water foliar spray + RDF \\
\hline $\mathbf{T}_{6}$ & Pramukh @ 5g/l of water foliar spray + RDF \\
\hline $\mathbf{T}_{7}$ & $\begin{array}{l}\text { Nano-Max NPK @ 4ml/l foliar spray + Pramukh @ 4g/l of water foliar spray } \\
\text { + RDF }\end{array}$ \\
\hline $\mathbf{T}_{\mathbf{8}}$ & Control (Only RDF) \\
\hline (RDF- Recommended Dose of Fertilizer@ $\left.125 \mathrm{kgN}: 60 \mathrm{kgP}_{2} \mathrm{O}_{5}: 100 \mathrm{~kg} \mathrm{~K} \mathrm{~K}_{2} \mathrm{O} / \mathrm{ha}\right)$ \\
\hline
\end{tabular}

Table.3 Effects of nano-fertilizer on reproductive growth of tomato

\begin{tabular}{|c|c|c|c|c|}
\hline \multicolumn{2}{|r|}{ Treatments } & \multirow{2}{*}{$\begin{array}{c}\begin{array}{c}\text { Days to } 1^{\text {st }} \\
\text { flowering } \\
\text { (DAS) }\end{array} \\
47.67\end{array}$} & \multirow{2}{*}{$\begin{array}{c}\begin{array}{c}\text { Days to } 50 \% \\
\text { flowering } \\
\text { (DAS) }\end{array} \\
51.00\end{array}$} & \multirow{2}{*}{$\begin{array}{c}\begin{array}{c}\text { Flowers per } \\
\text { cluster }\end{array} \\
8.73 \\
\end{array}$} \\
\hline $\mathbf{T}_{1}$ & Nano-Max NPK $(3 \mathrm{ml} / \mathrm{l})+$ RDF & & & \\
\hline $\mathbf{T}_{2}$ & Nano-Max NPK (4ml/l) + RDF & 47.67 & 53.00 & 9.30 \\
\hline $\mathbf{T}_{3}$ & Nano- Max NPK $(5 \mathrm{ml} / \mathrm{l})+\mathrm{RDF}$ & 46.67 & 51.00 & 9.50 \\
\hline $\mathbf{T}_{4}$ & Pramukh $(3 g / l)+R D F$ & 44.33 & 52.33 & 9.00 \\
\hline$T_{5}$ & $\operatorname{Pramukh}(4 \mathrm{~g} / \mathrm{l})+\mathrm{RDF}$ & 46.33 & 52.00 & 9.73 \\
\hline$T_{6}$ & Pramukh $(5 \mathrm{~g} / \mathrm{l})+\mathrm{RDF}$ & 45.67 & 51.67 & 9.30 \\
\hline $\mathbf{T}_{7}$ & $\begin{array}{l}\text { Pramukh }(4 \mathrm{~g} / \mathrm{l})+\text { Nano-Max NPK }(4 \mathrm{ml} / \mathrm{l})+ \\
\text { RDF }\end{array}$ & 46.67 & 53.67 & 9.00 \\
\hline $\mathbf{T}_{8}$ & Control (only RDF) & 45.33 & 51.33 & 9.37 \\
\hline & $\mathbf{S E}(\mathbf{m}) \pm$ & 1.10 & 1.13 & 0.33 \\
\hline & $\mathrm{CD}(0.05)$ & NS & NS & NS \\
\hline & $\mathrm{CV}(\%)$ & 4.13 & 3.77 & 6.27 \\
\hline
\end{tabular}


Table.4 Effects of nano-fertilizer on yield and yield attributes of tomato

\begin{tabular}{|c|c|c|c|c|c|c|c|c|}
\hline \multicolumn{2}{|r|}{ Treatments } & \multirow{2}{*}{$\begin{array}{c}\begin{array}{c}\text { Fruit } \\
\text { weigh } \\
\mathbf{t}(\mathbf{g})\end{array} \\
49.83\end{array}$} & \multirow{2}{*}{$\begin{array}{c}\begin{array}{c}\text { Fruit } \\
\text { length } \\
\text { (cm) }\end{array} \\
5.58\end{array}$} & \multirow{2}{*}{$\begin{array}{c}\begin{array}{c}\text { Fruit } \\
\text { Girth } \\
\text { (cm) }\end{array} \\
12.34\end{array}$} & \multirow{2}{*}{$\begin{array}{c}\begin{array}{c}\text { Fruits } \\
\text { per } \\
\text { cluster }\end{array} \\
5.80\end{array}$} & \multirow{2}{*}{$\begin{array}{c}\begin{array}{c}\text { Fruits } \\
\text { per } \\
\text { plant }\end{array} \\
51.60\end{array}$} & \multirow{2}{*}{$\begin{array}{c}\begin{array}{c}\text { Yield per } \\
\text { plot } \\
\text { (in kg) }\end{array} \\
19.91\end{array}$} & \multirow{2}{*}{\begin{tabular}{|c|}
$\begin{array}{c}\text { Yield } \\
\text { (q/ha) }\end{array}$ \\
368.70
\end{tabular}} \\
\hline $\mathbf{T}_{1}$ & $\begin{array}{ll}\text { Nano-Max } & \text { NPK } \\
(3 \mathrm{ml} / \mathrm{l})+\mathrm{RDF} & \end{array}$ & & & & & & & \\
\hline $\mathbf{T}_{2}$ & $\begin{array}{ll}\text { Nano-Max } & \text { NPK } \\
(4 \mathrm{ml} / \mathrm{l})+\mathrm{RDF} & \end{array}$ & 54.13 & 5.73 & 13.23 & 6.10 & 57.00 & 21.76 & 402.96 \\
\hline $\mathbf{T}_{3}$ & $\begin{array}{l}\text { Nano- Max } \\
(5 \mathrm{ml} / \mathrm{l})+\mathrm{NDF}\end{array}$ & 56.93 & 5.64 & 13.20 & 6.33 & 63.67 & 24.26 & 449.26 \\
\hline $\mathbf{T}_{4}$ & Pramukh $(3 g / 1)+$ RDF & 52.33 & 5.55 & 12.68 & 6.53 & 63.27 & 23.73 & 439.44 \\
\hline $\mathbf{T}_{5}$ & Pramukh $(4 g / l)+$ RDF & 49.97 & 5.44 & 12.35 & 6.53 & 66.33 & 27.50 & 509.26 \\
\hline $\mathbf{T}_{6}$ & $\operatorname{Pramukh}(5 \mathrm{~g} / \mathrm{l})+\mathrm{RDF}$ & 53.53 & 5.84 & 14.13 & 6.30 & 81.60 & 27.54 & 510.00 \\
\hline $\mathbf{T}_{7}$ & $\begin{array}{lr}\text { Pramukh }(4 \mathrm{~g} / \mathrm{l}) & + \\
\text { Nano-Max } & \text { NPK } \\
(4 \mathrm{ml} / \mathrm{l})+\mathrm{RDF}\end{array}$ & 55.60 & 5.61 & 13.60 & 6.50 & 63.20 & 21.69 & 401.67 \\
\hline $\mathbf{T}_{8}$ & Control (only RDF) & 54.50 & 5.59 & 13.01 & 6.87 & 62.07 & 23.00 & 425.93 \\
\hline \multicolumn{2}{|r|}{$\mathrm{SE}(\mathbf{m}) \pm$} & 2.24 & 0.15 & 0.44 & 0.24 & 4.42 & 1.46 & \\
\hline \multicolumn{2}{|r|}{$\operatorname{CD}(0.05)$} & 6.79 & NS & 1.34 & 0.74 & 13.41 & 4.43 & \\
\hline \multicolumn{2}{|r|}{$\mathrm{CV}(\%)$} & 7.27 & 4.75 & 5.86 & 6.60 & 12.05 & 10.68 & \\
\hline
\end{tabular}

Table.5 Final soil analysis of treatments

\begin{tabular}{|c|c|c|c|c|c|c|c|}
\hline & Treatments & $\begin{array}{c}\text { Total } \\
\text { nitrogen } \\
(\mathrm{kg} / \mathrm{ha})\end{array}$ & $\begin{array}{c}\text { Available } \\
\text { phosphorus } \\
\text { (kg/ha) }\end{array}$ & $\begin{array}{c}\text { Available } \\
\text { potassium } \\
\text { (kg/ha) }\end{array}$ & pH & $\begin{array}{c}\text { Electrical } \\
\text { conductivity } \\
(\mu S)\end{array}$ & $\begin{array}{c}\text { Organic } \\
\text { carbon }(\%)\end{array}$ \\
\hline $\mathbf{T}_{1}$ & $\begin{array}{l}\text { Nano-Max NPK } \\
(3 \mathrm{ml} / \mathrm{l})+\mathrm{RDF}\end{array}$ & 92.8 & 31.96 & 112.7 & 6.4 & 300.1 & 1.16 \\
\hline $\mathbf{T}_{2}$ & $\begin{array}{l}\text { Nano-Max NPK } \\
(4 \mathrm{ml} / \mathrm{l})+\mathrm{RDF}\end{array}$ & 78.0 & 29.67 & 97.8 & 6.2 & 276.8 & 0.97 \\
\hline $\mathbf{T}_{3}$ & $\begin{array}{l}\text { Nano- Max NPK } \\
(5 \mathrm{ml} / \mathrm{l})+\mathrm{RDF}\end{array}$ & 54.4 & 17.53 & 63.4 & 6.2 & 202.5 & 0.68 \\
\hline $\mathbf{T}_{4}$ & $\begin{array}{l}\text { Pramukh }(3 g / l)+ \\
\text { RDF }\end{array}$ & 72.0 & 15.89 & 86.2 & 6.3 & 290.6 & 0.90 \\
\hline $\mathbf{T}_{5}$ & $\begin{array}{l}\text { Pramukh }(4 g / l)+ \\
\text { RDF }\end{array}$ & 97.6 & 18.59 & 82.4 & 6.4 & 384.9 & 1.22 \\
\hline$T_{6}$ & $\begin{array}{l}\text { Pramukh }(5 g / l)+ \\
\text { RDF }\end{array}$ & 64.8 & 15.73 & 79.6 & 6.8 & 209.8 & 0.81 \\
\hline $\mathbf{T}_{7}$ & $\begin{array}{l}\text { Pramukh }(4 \mathrm{~g} / \mathrm{l})+ \\
\text { Nano-Max NPK } \\
(4 \mathrm{ml} / \mathrm{l})+\mathrm{RDF}\end{array}$ & 105.6 & 26.27 & 87.0 & 6.6 & 268.2 & 1.32 \\
\hline $\mathbf{T}_{8}$ & $\begin{array}{l}\text { Control (only } \\
\text { RDF) }\end{array}$ & 60.8 & 14.42 & 62.7 & 6.5 & 204.1 & 0.76 \\
\hline
\end{tabular}


Table.6 Economics of treatment

\begin{tabular}{|c|c|c|c|c|c|c|}
\hline \multicolumn{2}{|r|}{ Treatments } & \multirow{2}{*}{$\begin{array}{c}\begin{array}{c}\text { Yield } \\
\text { (q/ha) }\end{array} \\
368.70\end{array}$} & \multirow{2}{*}{$\begin{array}{c}\text { Gross income } \\
\text { (Yield } x \\
\text { Rs.10/- per kg) } \\
\text { (in rupees) } \\
3,68,700\end{array}$} & \multirow{2}{*}{$\begin{array}{c}\begin{array}{c}\text { Total cost } \\
\text { of } \\
\text { cultivation } \\
\text { (in rupees) }\end{array} \\
1,42,225\end{array}$} & \multirow{2}{*}{$\begin{array}{c}\begin{array}{c}\text { Net income } \\
\text { (in rupees) }\end{array} \\
2,26,475\end{array}$} & \multirow{2}{*}{$\begin{array}{c}\begin{array}{c}\text { Benefit/cost } \\
\text { ratio }\end{array} \\
2.59: 1\end{array}$} \\
\hline $\mathbf{T}_{1}$ & $\begin{array}{l}\text { Nano-Max NPK }(3 \mathrm{ml} / \mathrm{l})+ \\
\text { RDF }\end{array}$ & & & & & \\
\hline $\mathbf{T}_{2}$ & $\begin{array}{l}\text { Nano-Max NPK }(4 \mathrm{ml} / \mathrm{l})+ \\
\text { RDF }\end{array}$ & 402.96 & $4,02,960$ & $1,44,287$ & $2,58,673$ & $2.75: 1$ \\
\hline $\mathbf{T}_{3}$ & $\begin{array}{l}\text { Nano- Max NPK }(5 \mathrm{ml} / \mathrm{l})+ \\
\text { RDF }\end{array}$ & 449.26 & $4,49,260$ & $1,46,350$ & $3,02,910$ & $3.06: 1$ \\
\hline $\mathbf{T}_{4}$ & Pramukh $(3 g / l)+$ RDF & 439.44 & $4,39,440$ & $1,37,443.75$ & $3,01,996.25$ & $3.19: 1$ \\
\hline $\mathbf{T}_{5}$ & Pramukh $(4 g / l)+R D F$ & 509.26 & $5,09,260$ & $1,37,912.5$ & $3,71,347.5$ & $3.69: 1$ \\
\hline $\mathbf{T}_{6}$ & Pramukh $(5 g / l)+$ RDF & 510.00 & $5,10,000$ & $1,38,381.25$ & $3,71,618.75$ & $3.68: 1$ \\
\hline $\mathbf{T}_{7}$ & $\begin{array}{l}\text { Pramukh }(4 \mathrm{~g} / \mathrm{l})+\text { Nano-Max } \\
\text { NPK }(4 \mathrm{ml} / \mathrm{l})+\mathrm{RDF}\end{array}$ & 401.67 & $4,01,670$ & $1,49,443.75$ & $2,52,226.25$ & $2.68: 1$ \\
\hline $\mathbf{T}_{8}$ & Control (only RDF) & 425.93 & $4,25,930$ & $1,32,756.25$ & $2,93,173.75$ & $3.20: 1$ \\
\hline
\end{tabular}

\section{Fruits per cluster}

Significant differences were found regarding no. of fruits per cluster, which ranged between 5.80 and 6.87 (Table 4). $\mathrm{T}_{8}, \mathrm{~T}_{5}, \mathrm{~T}_{4}$, $\mathrm{T}_{7}, \mathrm{~T}_{3}$ and $\mathrm{T}_{6}$ were at par. Yassen et al., (2017) made similar observations. However, $\mathrm{T}_{8}$ recorded maximum (6.87) and $\mathrm{T}_{1}$ recorded minimum (5.80) no. of fruits per cluster.

\section{Fruits per plant}

It was evident from Table 4 that there were significant differences regarding no. of fruits per plant. However, $\mathrm{T}_{6}$ was superior to $\mathrm{T}_{5}, \mathrm{~T}_{3}$, $\mathrm{T}_{4}, \mathrm{~T}_{7}, \mathrm{~T}_{8}, \mathrm{~T}_{2}$ and $\mathrm{T}_{1}$ respectively. $\mathrm{T}_{8}$ was found to be at par with $\mathrm{T}_{1}, \mathrm{~T}_{2}, \mathrm{~T}_{3}$. Several researchers (Harish and Gowda (2017); ElMetwally et al., 2017; Yassen et al., 2017) made a similar observations. The highest (81.60) value was obtained in $\mathrm{T}_{6}$ and the lowest (51.60) was in $\mathrm{T}_{1}$.

\section{Yield per plot and per hectare}

Significant differences were found regarding yield per plot. $T_{6}, T_{5}, T_{3}$ and $T_{4}$ treatments were at par. $\mathrm{T}_{8}$ was found to be at par with $\mathrm{T}_{1}$,
$\mathrm{T}_{2}$ and $\mathrm{T}_{3}$. This is in agreement with the findings of several researchers (Owolade et al., 2008; Moghaddasi et al., 2013; Tantawy et al., 2014; Liu and Lal 2014; Khan 2016; Khanm et al., 2017; Davarpanah et al., 2017; Jyothi and Hebsur 2017; Raddy et al., 2017; Rathnayak et al., 2018). $\mathrm{T}_{6}, \mathrm{~T}_{5}, \mathrm{~T}_{3}$ and $\mathrm{T}_{4}$ were found superior than $T_{8}, T_{2}, T_{7}$ and $T_{1}$.

The highest yield (27.54 kg/plot) (510 q/ha) was obtained in $\mathrm{T}_{6}$ followed by $\mathrm{T}_{5}(509.26$ $\mathrm{q} / \mathrm{ha})$ and $\mathrm{T}_{3}(449.26 \mathrm{q} / \mathrm{ha})$ and the lowest yield (19.91 kg/plot) (368.7 $\mathrm{q} / \mathrm{ha})$ was recorded in $\mathrm{T}_{1}$ (Table 4 ).

\section{Final soil analysis of treatments}

\section{Total nitrogen (kg/ha)}

It was evident from Table 5 that the total nitrogen content of soil for different treatments varied from $54.4 \mathrm{~kg} / \mathrm{ha}\left(\mathrm{T}_{3}\right)$ to $105.6 \mathrm{~kg} / \mathrm{ha}\left(\mathrm{T}_{7}\right)$.

\section{Available phosphorus (kg/ha)}

A perusal of Table 5 showed that the available phosphorus of soil for different 
treatments ranged from $14.42 \mathrm{~kg} / \mathrm{ha}\left(\mathrm{T}_{8}\right)$ to $31.96 \mathrm{~kg} / \mathrm{ha}\left(\mathrm{T}_{1}\right)$.

\section{Available potassium (kg/ha)}

It was evident from Table 5 that the available potassium content of soil from different treatments ranged from $62.7 \mathrm{~kg} / \mathrm{ha}\left(\mathrm{T}_{8}\right)$ to $112.7 \mathrm{~kg} / \mathrm{ha}\left(\mathrm{T}_{1}\right)$.

\section{pH}

It was observed from Table 5 that the $\mathrm{pH}$ range varied for different treatments from 6.2 $\left(\mathrm{T}_{2}\right.$ and $\left.\mathrm{T}_{3}\right)$ to $6.8\left(\mathrm{~T}_{6}\right)$.

\section{Electrical conductivity $(\mu S)$}

It was seen from Table 5 that electrical conductivity ranged for different treatments from $204.1 \mu \mathrm{S}\left(\mathrm{T}_{8}\right)$ to $384.9 \mu \mathrm{S}\left(\mathrm{T}_{5}\right)$.

\section{Organic carbon $(\%)$}

It was observed from Table 5 that organic carbon for different treatments ranged from $0.68 \%\left(\mathrm{~T}_{3}\right)$ to $1.32 \%\left(\mathrm{~T}_{7}\right)$.

\section{Economics of treatments}

A perusal of Table 6 showed that gross income was highest in case of the treatment $\mathrm{T}_{6} \quad$ (Rs.5,10,000/-) followed by $\mathrm{T}_{5}$ (Rs.5,09,260/-) and $\mathrm{T}_{3}$ (Rs.4,49,260/-) and the minimum was seen in $\mathrm{T}_{1}$ (Rs.3,68,700/-). Total cost of cultivation was found minimum for $\mathrm{T}_{8}$ (Rs.1,32,756.25/-) followed by $\mathrm{T}_{4}$ (Rs.1,37,443.75/-) and $\mathrm{T}_{5}$ (Rs.1,37,912.5/-) and the maximum was observed in case of $\mathrm{T}_{7}$ (Rs.1,49,443.75/-). Net income was maximum in $\mathrm{T}_{6}$ treatment (Rs.3,71,618.75/-) followed by $\mathrm{T}_{5}$ (Rs.3,71,347.5/-) and $\mathrm{T}_{3}$ (Rs.3,02,910/-) and the least was seen in $\mathrm{T}_{1}$ (Rs. 2,26,475/).The highest $\mathrm{B}: \mathrm{C}$ ratio was recorded in $\mathrm{T}_{5}$ (3.69) followed by $\mathrm{T}_{6}$ (3.68) and $\mathrm{T}_{8}$ (3.20) and the lowest was in $\mathrm{T}_{1}(2.59)$.
The treatment $\mathrm{T}_{6}$ (Pramukh foliar spray@ 5g/l $+\mathrm{RDF}$ ) was found to be the best with respect to the characters fruit yield/ha, fruits per plant, fruit length and fruit girth. As regards average fruit weight, $\mathrm{T}_{3}$ (Nano-Max NPK foliar spray @ 5ml/l + RDF) was the best. The treatment $\mathrm{T}_{5}$ (Pramukh foliar spray @4g/l + RDF) produced the maximum no. of flowers per cluster and the treatments $\mathrm{T}_{1}$ and $\mathrm{T}_{3}$ recorded early $50 \%$ flowering. The treatment $\mathrm{T}_{5}$ recoredhighest benefit: cost ratio and $2^{\text {nd }}$ highest yield followed by the treatment $T_{6}$ having highest yield and $2^{\text {nd }}$ highest benefit: cost ratio.

\section{Acknowledgement}

The authors are grateful to the Department of Horticulture, Institute of Agricultural Sciences, Siksha 'O' Anusandhan (Deemed to be University), Bhubaneswar, for providing the physical and financial facilities required for conducting the experiment.

\section{References}

Ambroszczyk A.M., Jedrszczyk E. and Nowicka-Polec A. 2016.The influence of Nano-Gro® stimulator on growth, yield and quality of tomato fruit Lycopersicon esculentum Mill. in plastic tunnel cultivation. Acta Horticulturae, 8: 12-16.

Bouyoucos G.J. 1962. Hydrometer method improved for making particle size analysis of soils. Agronomy Journal, 54: 464-465.

Davarpanah S., Tehranifar A., Davarynejad G., Aran M., Abadía J. and Khorassani R. 2017. Effects of foliar nano-nitrogen and urea fertilizers on the physical and chemical properties of pomegranate Punica granatum cv. Ardestani fruits. Horticultural Science, 522: 288-29.

El-Metwally I.M., Abo-Basha D.M.R. and Abd El-Aziz M.E. 2018. Response of 
peanut plants to different foliar applications of nano- iron, manganese and zinc under sandy soil conditions. Middle East Journal of Applied Sciences, 82: 474-482.

Harish M.S. and Gowda R. 2017. Effect of nanoscale zinc oxide on plant growth, seed yield and quality in groundnut. Mysore Journal of Agricultural Sciences, 513: 637-643.

https://actascientific.com/ASAG/pdf/ASAG02-0108.pdf

https://homeguides.sfgate.com/disadvantagesinorganic-fertilizer-64756.html

https://www.indiamart.com/proddetail/nanomax-npk-fertilizer-12188041548.html

https://www.indiamart.com/proddetail/pramu kh-fertilizer-19104737930.html

Jackson M.L. 1973.Soil chemical analysis, Prentice Hall of India Pvt. Ltd., New Delhi.

Jyothi T.V. and Hebsur N.S. 2017. Effect of nanofertilizers on growth and yield of selected cereals - A review. Agricultural Reviews, 382: 112-120.

Khan M.N. 2016. Nano-titanium dioxide nano$\mathrm{TiO}_{2}$ mitigates $\mathrm{NaCl}$ stress by enhancing antioxidative enzymes and accumulation of compatible solutes in tomato Lycopersicon esculentum Mill. Journal of Plant Sciences, 11: 1-11.

Khanm H., Vaishnavi B.A., Namratha M.R. and Shankar A.G. 2017. Nano zinc oxide boosting growth and yield in Tomato: the rise of "nano fertilizer era". International Journal of Agricultural Science and Research, 73: 197-206.

Laware S.L. and Raskar S. 2014. Influence of zinc oxide nanoparticles on growth, flowering and seed productivity in onion. International Journal of Current Microbiology and Applied Sciences,37: 874-881.

Liu R.Q. and Lal R. 2014. Synthetic apatite nanoparticles as a phosphorus fertilizer for soybean Glycine max.Scientific
Reports,4: 1-6.

Moghaddasi S., Khoshgoftarmanesh A.H., Karimzadeh F. and Chaney R.L. 2013. Preparation of nano-particles from waste tire rubber and evaluation of their effectiveness as zinc source for cucumber in nutrient solution culture. Scientia Horticulturae, 160: 398-403.

Olsen S.R., Cole C.V., Watanabe F.S. and Dean L.A. 1954. Estimation of available phosphorous by extraction with sodium bicarbonate. United States Department of Agriculture Circular, 939.

Owolade O.F., Ogunleti D.O. and Adenekan M.O. 2008. Titanium dioxide affects diseases, development and yield of edible cowpea. Electronic Journal of Environmental, Agricultural and Food chemistry, 75: 2942-2947.

Panse V.G. and Sukhatme P.V. 1985. Statistical Methods for Agricultural Workers. Indian Council of Agricultural Research, New Delhi.

Raddy R., Pavithra G.J., Mahesh S., Geetha K.N. and Shankar A.G. 2017. Seed priming and foliar spray with nano zinc improves stress adaptability and seed zinc content without compromising seed yield in ragi Finger millet.International Journal of Pure \& Applied Bioscience, 53: 251-258.

Rathnayaka R.M.N.N., Mahendran S., Iqbal Y.B., Rifnas L.M. 2018. Influence of urea and nano-nitrogen fertilizers on the growth and yield of rice Oryza sativa $\mathrm{L}$. cultivar 'Bg 250'. International Journal of Research Publications, 52: 1-7.

Shukla S., Shukla P.K., Pandey H., Ramteke P.W. and Misra P. 2017. Effect of different modes and concentrations of $\mathrm{ZnO}$ nano particles on floral properties of sunflower variety SSH6163. Vegetos, 30: 307-314.

Tantawy A.S., Salama Y.A.M., AbdelMawgoud A.M.R. and Ghoname A.A. 2014. Comparison of chelated calcium 
with nano calcium on alleviation of salinity negative effects on tomato plants.Middle East Journal of Agriculture Research, 34: 912-916.

Walkley A. and Black I.A. 1934. An examination of the Degtjareff method for determining soil organic matter and a proposed modification of the chromic acid titration method.Soil Science,37:
29-38.

Yassen A., Abdallah E., Gaballah M. and Zaghloul S. 2017. Role of silicon dioxide nano fertilizer in mitigating salt stress on growth, yield and chemical composition of cucumber Cucumis sativus L. International Journal of Agricultural Research, 12: 130-135.

\section{How to cite this article:}

Janmejaya Panda, Alok Nandi, Siba Prasad Mishra, Asit Kumar Pal, Ajoy Kumar Pattnaik and Nitish Kumar Jena. 2020. Effects of Nano Fertilizer on Yield, Yield Attributes and Economics in Tomato (Solanum lycopersicum L.). Int.J.Curr.Microbiol.App.Sci. 9(05): 2583-2591. doi: https://doi.org/10.20546/ijcmas.2020.905.295 